\title{
Risk factors of postoperative delirium in the knee and hip replacement patients: a systematic review and meta-analysis
}

\author{
Xiao Rong ${ }^{\dagger}$, Zi-chuan Ding ${ }^{\dagger}$, Hao-da Yu, Shun-Yu Yao and Zong-Ke Zhou* ${ }^{*}$
}

\begin{abstract}
Background: The risk factors of postoperative delirium (POD), a serious while preventable complication, developed by patients undergoing knee and replacement surgery are still under investigation. In this systematic review and meta-analysis, we identified risk factors associated with POD in knee and hip replacement.

Methods: PubMed, Ovid MEDLINE, and Ovid EMBASE were used to identify original researches. The studies evaluating the risk factors of POD after knee and hip replacement were reviewed, and the qualities of the included studies were assessed with Newcastle-Ottawa Scale. Data were extracted, pooled, and a meta-analysis was completed

Result: Twenty-two studies were finally included with a total of 11934 patients who underwent knee or hip replacement and 1841 developed POD with an incidence of 17.6\% (95\% confidential interval (CI) 13.2-22.0\%). Eighteen significant risk factors were identified including advanced age (odds ratio (OR) 1.15 95\% Cl 1.08-1.22), cognitive impairment (OR 6.84, 95\% Cl 3.27-14.33), history of cerebrovascular events (OR 2.51, 95\% Cl 1.28-4.91), knee replacement (OR 1.42, 95\% Cl 1.00-2.02), blood loss (standardized mean difference (SMD) $0.30,95 \%$ Cl $0.15-$ 0.44), dementia (OR 3.09, 95\% Cl 2.10-4.56), neurologic disorders (OR 2.26, 95\% Cl 1.23-4.15), psychiatric illness (OR $2.74,95 \% \mathrm{Cl} 1.34-5.62)$, and obstructive sleep apnea (OR 4.17, 95\% Cl 1.72-10.09) along with several comorbidity evaluation scores and laboratory markers.
\end{abstract}

Conclusion: We identified risk factors consistently associated with the incidence of POD in knee and hip replacement. Strategies and interventions should be implemented to the patients receiving knee or hip replacement with potential risk factors identified in this meta-analysis.

Keywords: Knee replacement, Hip replacement, Postoperative delirium, Risk factors

\footnotetext{
* Correspondence: zhouzongke@scu.edu.cn

${ }^{+}$Xiao Rong and Zi-chuan Ding contributed equally to this work.

Department of Orthopedics, West China Hospital/West China School of Medicine, Sichuan University, 37\# Wuhou Guoxue road, Chengdu 610041, People's Republic of China
}

C C The Author(s). 2021 Open Access This article is licensed under a Creative Commons Attribution 4.0 International License, which permits use, sharing, adaptation, distribution and reproduction in any medium or format, as long as you give appropriate credit to the original author(s) and the source, provide a link to the Creative Commons licence, and indicate if changes were made. The images or other third party material in this article are included in the article's Creative Commons licence, unless indicated otherwise in a credit line to the material. If material is not included in the article's Creative Commons licence and your intended use is not permitted by statutory regulation or exceeds the permitted use, you will need to obtain permission directly from the copyright holder. To view a copy of this licence, visit http://creativecommons.org/licenses/by/4.0/ The Creative Commons Public Domain Dedication waiver (http://creativecommons.org/publicdomain/zero/1.0/) applies to the data made available in this article, unless otherwise stated in a credit line to the data. 


\section{Background}

Knee and hip replacement surgeries have been performed for decades and are the most common procedures in the orthopedic department. Annually, there would be 512,000 hip replacement and 700,000 knee replacement in the USA [1,2], and the demand continues to grow worldwide for the outcomes are satisfying based on pain relief and function improvement. Mainly, these procedures are performed in the age group of those older than 60 years $[1,2]$. However, complications may disturb the rehabilitation and outcomes of the procedures, and postoperative delirium (POD) serves as a very common one.

As an acute decline in cognitive function, POD is serious and costly which mainly affects elderly people aged 65 years and older with an incidence rate of $12-51 \%$ in orthopedic surgery [3]. It is associated with an increase in mortality and morbidity, prolonged length of hospital stay, and worse surgical outcomes [3, 4]. However, POD is preventable with multi-component and targeted interventions which aim to optimize the mobility, nutrition, orientation, cognitive function, and sleep $[5,6]$. Therefore, identifying the patients with the potential risks of developing POD, for whom to receive the specific interventions, is important. Numerous risk factors have been identified in the medical, surgical, and intensive care clinical population, while, to be specific, the risk factors in the knee and hip replacement of POD are still under investigation $[3,7]$. In joint replacement surgery, a metaanalysis revealed that $17 \%$ of patients who underwent total knee or hip replacement surgery developed POD [8], and a systematic review summarized that general anesthesia, advanced age, history of psychiatric illness, decreased functional status, and specific anesthetic agents would raise the POD rate [9]. However, the existing meta-analysis and systematic reviews have not provided the pooled estimation of risk factors or only summarized the incidence of POD in the knee and hip replacement.

As the elderly population is in the majority of patients undergoing knee or hip replacement which is also at a higher risk of POD, understanding the delirium risk factors may help the surgeons, patients, therapists, and caregivers in providing targeting interventions. The current meta-analysis aims to pool the prevalence and risk factors of POD in patients undergoing knee or hip replacement surgery from existing literature as no formal systematic review or meta-analysis has been performed to date. The result would be helpful and could be used by the clinical team of the joint replacement department in optimizing the perioperative program aiming at lowering the incidence of POD among patients undergoing knee and hip replacement.

\section{Methods}

\section{Literature search}

The PubMed, Ovid MEDLINE, and Ovid EMBASE were used to identify original research published all through March 2020 with following keywords: "joint replacement," "joint arthroplasty," "knee replacement," "knee arthroplasty," "hip replacement," "hip arthroplasty," “TJR," “TJA," “TKR," “TKA," “THR," "THA," “delirium," and "confusion." References in identified articles and systematic reviews were scanned manually for possible inclusion.

\section{Eligibility criteria}

The original studies included in this meta-analysis should meet the criteria as follows: (1) only assessing patients who underwent knee or hip replacement, (2) available prevalence or risk factors of POD or data from POD and non-POD patients, (3) used any validated tools (Diagnostic and Statistical Manual of Mental Disorders (DSM) [10], Confusion Assessment Method (CAM) [11], or Delirium Rating Scale (DRS) [12], etc.) for POD assessment; and (4) cohort, case-control, and cross-section studies. Studies assessing delirium after discharge and subsyndromal delirium or any other kind of cognitive impairment were not included.

\section{Study selection}

Endnote was used for two levels of screening by two reviewers. Firstly, we screen the titles and abstracts of the articles based on the inclusion criteria for eligible studies. Secondly, the full-text articles were screened. After that, disagreements of the inclusion and exclusion of the articles were discussed to reach the final agreement between the two reviewers. The flow diagram was presented in Fig. 1 and supplement file 1, and the PRISMA checklist was presented in supplement file 2 .

\section{Data extraction}

Two reviewers independently extracted the data from the included studies. At first, the characteristics including titles, authors, year of publication, study design, sample size, type of surgery, and assessment tools of the included studies would be summarized. Then, the risk factors of POD from the included studies were extracted. Importantly, the definitions of each risk factor from different studies were also extracted to prevent misunderstanding. When multiple studies reported the data from the same source, we would adopt the study with the longest follow-up, the largest sample size, or more valid data. Missing data were sought from the corresponding authors where possible. Finally, the disagreements of the extracted data were resolved through discussion. 


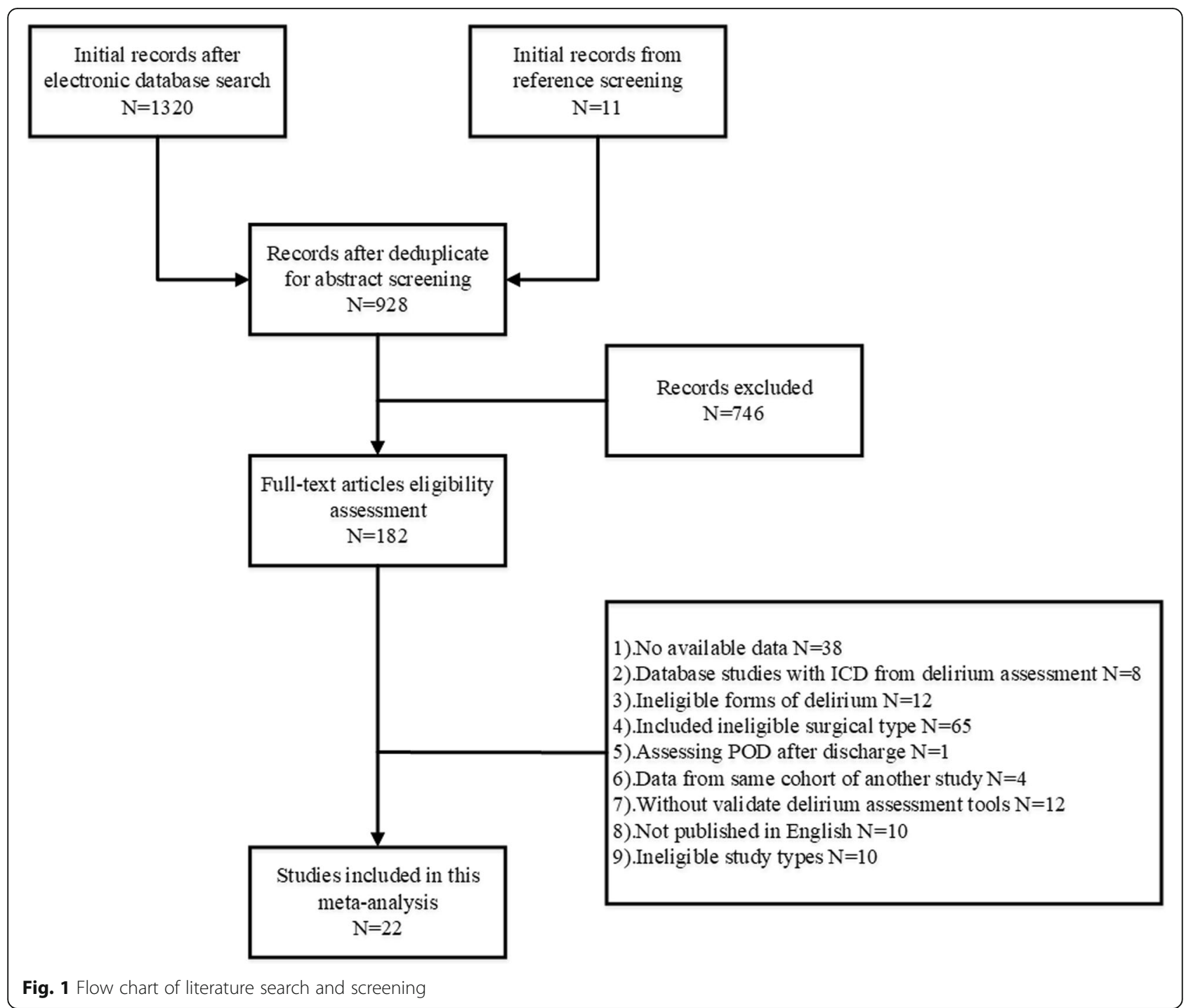

\section{Methodological quality assessment}

The non-randomized studies included in this metaanalysis were assessed with the Newcastle-Ottawa Scale (NOS) [13] by two independent reviewers. It is a validated and recommended tool for non-randomized studies' methodological quality describing. The scores of NOS consist of selection criteria, comparability, and outcome (cohort study) or exposure (case-control study). A maximum of 9 scores reveals the highest quality.

\section{Statistical analysis}

The odds ratios (ORs) or standardized mean differences (SMDs) with 95\% confidential intervals (CIs) were calculated and pooled where a risk factor was examined by two or more included studies to estimate the association between the risk factors and POD. The between-study heterogeneity was tested with $I^{2}$ which was guided by the Cochrane Handbook for Systematic Reviews of
Interventions. The random-effect model was used to calculate the pooled ORs or SMDs when significant heterogeneity was presented $\left(I^{2}>50 \%\right)$. And the fixed-effect model was used in the absence of statistical heterogeneity. Incidences of delirium were pooled by the randomeffect model which drives an overall effect estimate with 95\% CIs. A statistically significant risk factor for POD was considered at a two-tailed $p$ value $<0.05$. Forest plots were used to summarize the outcomes of metaanalyses. For a risk factor demonstrated by at least 10 studies, we assessed for the potential publication bias with visual funnel plots for symmetry and Eggar's test. When a statistically significant bias was demonstrated ( $p$ $<0.05$ ), a trim-and-fill method was used to reveal the missing studies and, adjusting for publication bias, provide a combined effect estimate. All statistical analyses were conducted in StataSE 15.0 using metan and associating modules. 
Table 1 Characteristics of the included studies

\begin{tabular}{|c|c|c|c|c|c|c|c|c|c|c|}
\hline Author & Year & Study design & $\begin{array}{l}\text { Type of } \\
\text { surgery }\end{array}$ & Age & $\begin{array}{l}\text { Sample } \\
\text { size }\end{array}$ & $\begin{array}{l}\text { Case of } \\
\text { delirium }\end{array}$ & Incidence & $\begin{array}{l}\text { Gender } \\
\text { female/male }\end{array}$ & $\begin{array}{l}\text { Criteria for } \\
\text { delirium }\end{array}$ & $\begin{array}{l}\text { Study quality } \\
\text { (stars) }\end{array}$ \\
\hline de Jong & 2019 & Case control & Hip & $81 \pm 8$ & 463 & 121 & $26.1 \%$ & $310 / 206$ & DSM-IV & 6 \\
\hline $\mathrm{Guo}^{\mathrm{a}}$ & 2019 & $\begin{array}{l}\text { Prospective } \\
\text { cohort }\end{array}$ & Hip & $65-80$ & 244 & 60 & $24.6 \%$ & $67 / 53^{a}$ & CAM & 9 \\
\hline Peng & 2019 & $\begin{array}{l}\text { Prospective } \\
\text { cohort }\end{array}$ & $\begin{array}{l}\text { Knee and } \\
\text { hip }\end{array}$ & $65-85$ & 272 & 55 & $20.2 \%$ & $157 / 115$ & DSM-V & 8 \\
\hline Cunningham & 2019 & $\begin{array}{l}\text { Prospective } \\
\text { cohort }\end{array}$ & $\begin{array}{l}\text { Knee and } \\
\text { hip }\end{array}$ & $\geq 65$ & 282 & 40 & $14.2 \%$ & $159 / 123$ & CAM & 7 \\
\hline Tak kyu & 2018 & Case control & Knee & $\begin{array}{l}71.0 \pm \\
6.9\end{array}$ & 6020 & 992 & $16.5 \%$ & $5511 / 509$ & CAM-ICU & 8 \\
\hline Choi & 2017 & $\begin{array}{l}\text { Prospective } \\
\text { cohort }\end{array}$ & Hip & $\geq 70$ & 356 & 110 & $30.9 \%$ & $290 / 66$ & $\begin{array}{l}\text { CAM and CAM- } \\
\text { ICU }\end{array}$ & 8 \\
\hline Xin & 2017 & $\begin{array}{l}\text { Prospective } \\
\text { cohort }\end{array}$ & Hip & $>65$ & 120 & 30 & $25.0 \%$ & $58 / 62$ & Nu-DESC & 8 \\
\hline Wang & 2017 & Case control & Knee & $>65$ & 265 & 49 & $18.5 \%$ & $244 / 21$ & CAM & 6 \\
\hline Culley & 2017 & $\begin{array}{l}\text { Prospective } \\
\text { cohort }\end{array}$ & $\begin{array}{l}\text { Knee and } \\
\text { hip }\end{array}$ & $\geq 65$ & 211 & 14 & $6.6 \%$ & $127 / 84$ & CAM & 8 \\
\hline Huang & 2017 & Case control & Knee & $N / A^{b}$ & 1016 & 6 & $0.6 \%$ & $827 / 189$ & DSM-IV & 6 \\
\hline Yen & 2016 & $\begin{array}{l}\text { Prospective } \\
\text { cohort }\end{array}$ & Knee & $\geq 65$ & 98 & 22 & $22.4 \%$ & $51 / 47$ & CAM and DRS-R98 & 9 \\
\hline Guo & 2016 & $\begin{array}{l}\text { Prospective } \\
\text { cohort }\end{array}$ & Hip & $\geq 65$ & 572 & 120 & $21.0 \%$ & $366 / 206$ & CAM & 8 \\
\hline Chung & 2015 & Case control & Knee & $>65$ & 365 & 11 & $3.0 \%$ & $332 / 33$ & CAM and DSM-IV & 7 \\
\hline Cerejeira & 2013 & $\begin{array}{l}\text { Prospective } \\
\text { cohort }\end{array}$ & Hip & $\geq 60$ & 101 & 37 & $36.6 \%$ & $51 / 50$ & $\begin{array}{l}\text { CAM and } \\
\text { DSM-IV-TR }\end{array}$ & 8 \\
\hline Flink & 2012 & $\begin{array}{l}\text { Prospective } \\
\text { cohort }\end{array}$ & Knee & $\geq 65$ & 106 & 27 & $25.5 \%$ & $59 / 47$ & $\begin{array}{l}\text { CAM, DSM-IV, } \\
\text { and DRS-R-98 }\end{array}$ & 9 \\
\hline Jankowski & 2011 & $\begin{array}{l}\text { Prospective } \\
\text { cohort }\end{array}$ & $\begin{array}{l}\text { Knee and } \\
\text { hip }\end{array}$ & $\geq 65$ & 418 & 42 & $10.0 \%$ & $212 / 206$ & CAM & 9 \\
\hline Lowery & 2008 & $\begin{array}{l}\text { Prospective } \\
\text { cohort }\end{array}$ & $\begin{array}{l}\text { Knee and } \\
\text { hip }\end{array}$ & $>70$ & 94 & 14 & $14.9 \%$ & $53 / 41$ & CAM & 7 \\
\hline Priner & 2008 & $\begin{array}{l}\text { Prospective } \\
\text { cohort }\end{array}$ & $\begin{array}{l}\text { Knee and } \\
\text { hip }\end{array}$ & $\begin{array}{l}73.6 \pm \\
6.6\end{array}$ & 101 & 15 & $14.9 \%$ & $58 / 43$ & CAM & 7 \\
\hline Wacker ${ }^{a}$ & 2006 & Case control & $\begin{array}{l}\text { Knee and } \\
\text { hip }\end{array}$ & $\geq 60$ & 572 & 31 & $5.4 \%$ & $20 / 9^{a}$ & DSM-IV & 7 \\
\hline Freter & 2005 & $\begin{array}{l}\text { Prospective } \\
\text { cohort }\end{array}$ & $\begin{array}{l}\text { Knee and } \\
\text { hip }\end{array}$ & $>65$ & 132 & 18 & $13.6 \%$ & $88 / 44$ & CAM & 5 \\
\hline Fisher & 1995 & $\begin{array}{l}\text { Prospective } \\
\text { cohort }\end{array}$ & $\begin{array}{l}\text { Knee and } \\
\text { hip }\end{array}$ & $\geq 60$ & 80 & 14 & $17.5 \%$ & $43 / 37$ & CAM & 6 \\
\hline Rogers & 1989 & $\begin{array}{l}\text { Prospective } \\
\text { cohort }\end{array}$ & $\begin{array}{l}\text { Knee and } \\
\text { hip }\end{array}$ & $\geq 60$ & 46 & 13 & $28.3 \%$ & $31 / 15$ & DSM-III & 5 \\
\hline
\end{tabular}

Abbreviations: DSM Diagnostic and Statistical Manual of Mental Disorders, CAM Confusion Assessment Method, ICU intensive care unit, Nu-DESC Nursing Delirium Screening Scale, DRS-R98 Delirium Rating Scale-Revised-98

${ }^{a}$ Data other than incidence were presented in baseline matched cohorts

${ }^{b}$ Information of age was separately reported for POD and non-POD groups

\section{Result}

\section{Characteristics of studies}

One thousand three hundred twenty abstracts and titles were included from the initial electronic search. After deduplication, 928 abstracts were scanned based on eligibility criteria which excluded 746 studies and the remaining 182 were screened with full text (Fig. 1). Finally, 22 studies (Table 1) [14-35] with a total of 11934 patients were included in this meta-analysis and in which 1841 cases were found with POD. Four studies [36-39] were excluded due to sharing the same cohorts with included ones $[15,17,27]$ which derived the longest follow-up. The result of methodological assessment demonstrated a moderate to high quality of the included studies (Table 2) in which four studies scored 9 [15, 24, 28, 29], seven studies scored 8 [14, 18, 19, 22, 23, 25, 27], five 


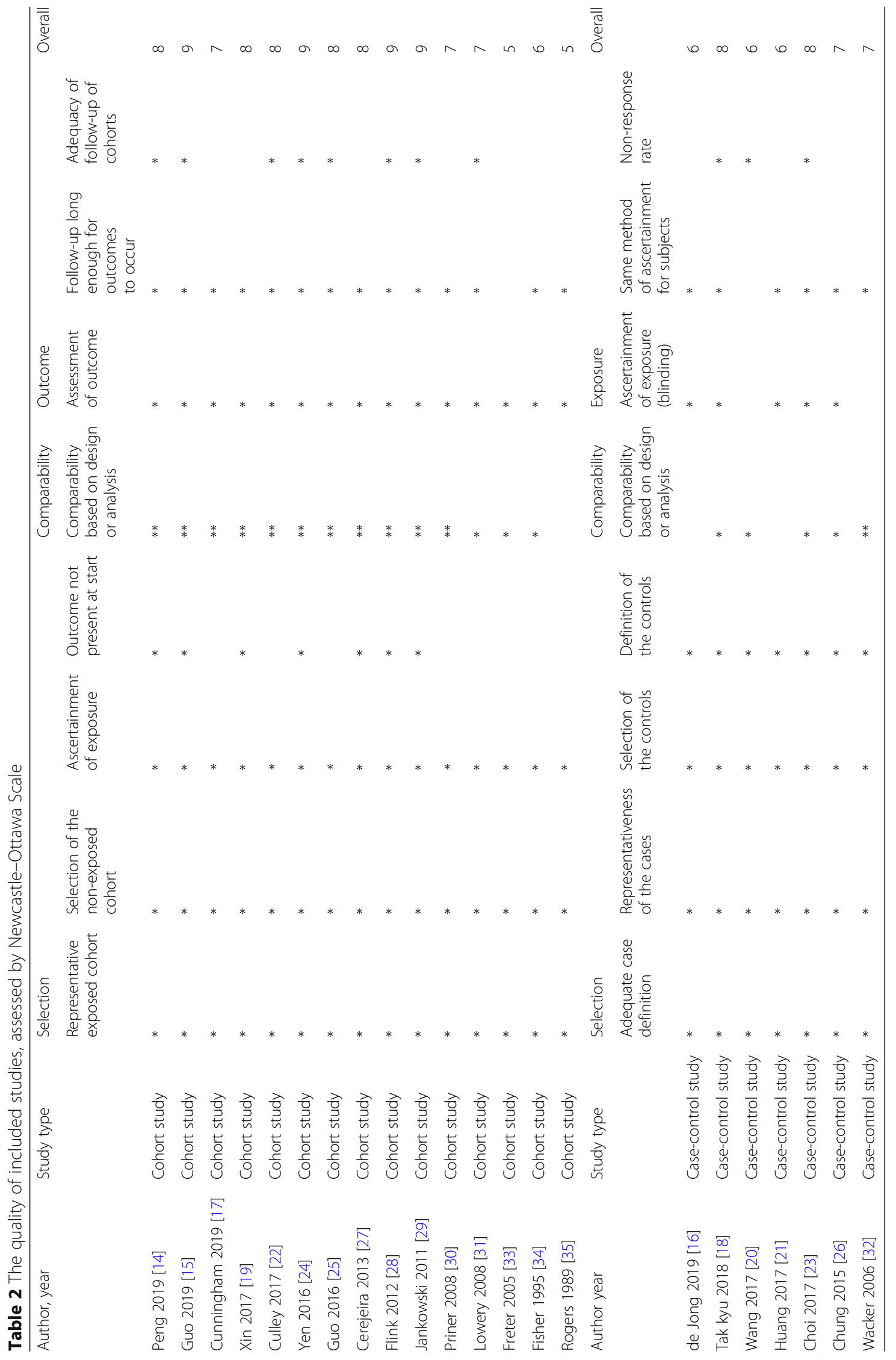


Table 3 Information of all the potential risk factors for delirium after knee and hip replacement

\begin{tabular}{|c|c|c|c|c|c|}
\hline Potential risk factors & No. of studies & Pooled ORs or SMDs & $95 \% \mathrm{Cl}$ & $p$ value & $I^{2}$ \\
\hline \multirow[t]{2}{*}{ Age } & 15 & $0.43^{a}$ & $(0.24,0.61)$ & $<0.001$ & $73.4 \%$ \\
\hline & 11 & 1.15 & $(1.08,1.22)$ & $<0.001$ & $63.5 \%$ \\
\hline Female (compared with male) & 14 & 0.91 & $(0.82,1.18)$ & 0.851 & $49.0 \%$ \\
\hline $\mathrm{BMI}$ & 7 & $-0.22^{\mathrm{a}}$ & $(-0.55,0.12)$ & 0.207 & $81.4 \%$ \\
\hline Education (years) & 6 & $-0.18^{\mathrm{a}}$ & $(-0.35,-0.02)$ & 0.026 & $0.0 \%$ \\
\hline MMSE & 11 & $-0.32^{\mathrm{a}}$ & $(-0.52,-0.13)$ & 0.001 & $57.1 \%$ \\
\hline Cognitive impairment & 3 & 6.84 & $(3.27,14.33)$ & $<0.001$ & $0.0 \%$ \\
\hline Dementia & 5 & 3.09 & $(2.10,4.56)$ & $<0.001$ & $38.6 \%$ \\
\hline Neurological disorders & 5 & 2.26 & $(1.23,4.15)$ & $<0.001$ & $0.0 \%$ \\
\hline Psychiatric illness & 2 & 2.74 & $(1.34,5.62)$ & 0.006 & $0.0 \%$ \\
\hline Obstructive sleep apnea & 2 & 4.17 & $(1.72,10.09)$ & 0.002 & $0.0 \%$ \\
\hline Knee replacement & 6 & 1.42 & $(1.00,2.02)$ & 0.048 & $9.8 \%$ \\
\hline Duration of surgery & 7 & $0.29^{\mathrm{a}}$ & $(0.06,0.52)$ & 0.013 & $57.4 \%$ \\
\hline Blood loss & 4 & $0.30^{\mathrm{a}}$ & $(0.15,0.44)$ & $<0.001$ & $0.0 \%$ \\
\hline Spinal anesthesia (compared with general) & 5 & 0.62 & $(0.46,0.85)$ & 0.003 & $45.7 \%$ \\
\hline History of cerebrovascular events & 4 & 2.51 & $(1.28,4.91)$ & 0.007 & $58.4 \%$ \\
\hline$A S A \geq 3$ & 8 & 1.59 & $(1.25,2.03)$ & $<0.001$ & $29.3 \%$ \\
\hline $\mathrm{CCl}$ & 5 & $0.35^{\mathrm{a}}$ & $(0.04,0.66)$ & 0.029 & $56.9 \%$ \\
\hline Length of stay & 6 & $0.53^{\mathrm{a}}$ & $(0.20,0.87)$ & 0.002 & $56.7 \%$ \\
\hline Total protein & 2 & $-0.68^{a}$ & $(-0.87,-0.48)$ & $<0.001$ & $0.0 \%$ \\
\hline Albumin & 2 & $-0.77^{\mathrm{a}}$ & $(-1.36,-0.19)$ & 0.009 & $71.6 \%$ \\
\hline Hemoglobin & 6 & $-0.58^{\mathrm{a}}$ & $(-1.11,-0.04)$ & 0.034 & $94.4 \%$ \\
\hline Creatine & 3 & $0.16^{a}$ & $(-0.00,0.32)$ & 0.051 & $0.0 \%$ \\
\hline C-Reactive protein & 2 & $0.76^{\mathrm{a}}$ & $(-0.88,2.41)$ & 0.363 & $96.2 \%$ \\
\hline Blood glucose & 2 & $0.41^{a}$ & $(-0.67,1.51)$ & 0.463 & $91.7 \%$ \\
\hline Alcohol abuse & 3 & 0.69 & $(0.32,1.46)$ & 0.329 & $76.7 \%$ \\
\hline Diabetic mellitus & 8 & 1.09 & $(0.86,1.40)$ & 0.476 & $29.7 \%$ \\
\hline Hypertension & 7 & 1.06 & $(0.88,1.29)$ & 0.522 & $0.0 \%$ \\
\hline Pulmonary disorders & 3 & 1.13 & $(0.70,1.82)$ & 0.61 & $0.0 \%$ \\
\hline Tobacco usage & 3 & 1.22 & $(0.68,2.19)$ & 0.507 & $0.0 \%$ \\
\hline
\end{tabular}

Abbreviations: $O R$ odds ratio, SMD standardized mean difference, $C l$ confident interval, BMI body mass index, MMSE Mini-Mental State Examination, ASA American Society of Anesthesiologists, $\mathrm{CCl}$ Charlson Comorbidity Index

${ }^{\text {a Data }}$ represents pooled SMD

studies scored $7[17,26,30-32]$, four studies scored $6[16$, $20,21,34]$, and two studies scored 5 [33, 35]. A total of 28 potential risk factors were initially summarized in this meta-analysis (Table 3).

\section{Incidence of POD}

All the included studies reported the incidence of POD which range from 0.6 to $36.6 \%$. A pooled incidence of POD was $17.6 \%$ (Fig. 2a, 22 studies, 11934 patients, 95\% CI $\left.13.2-22.0 \%, I^{2}=98.6 \%\right)$. Separately, for knee replacement, a pooled incidence was $16.4 \%$ (Fig. $2 \mathrm{~b}, 11$ studies, 8439 patients, $95 \%$ CI $10.1-22.8 \%, I^{2}=99.0 \%$ ), and for hip replacement, it was $18.8 \%$ (Fig. 2b, 11 studies, 2406 patients, $95 \%$ CI $15.8-26.2 \%, I^{2}=89.8 \%$ ).

\section{Risk factors}

\section{Advanced age}

A total of 15 studies reported the mean age in POD and non-POD groups, and a pooled SMD revealed that POD patients were mildly older (Fig. 3a, SMD 0.43 years, $95 \%$ CI 0.24-0.61, $p<0.001, I^{2}=73.4 \%$ ) than the non-POD patients. Further, 11 studies reported advanced age as a prognostic factor for POD with a pooled OR of 1.15 (Fig. 3b, 95\% CI 1.08-1.22, $p<0.001, I^{2}=63.5 \%$ ). Funnel plots showed a significant asymmetry (Fig. 3c, Eggar's $p$ 
Stud

ID

Rogers, M. P. (1989)

Bruce W. Fisher (1995)

Susan H Freter (2005)

Priscilla Wacker (2006)

David Peter Lowery (2008)

Mathieu Priner (2008)

Christopher J. Jankowski (2011)

Benjamin J. Flink (2012)

Joaquim Cerejeira (2013)

Kyu Sung Chung (2015)

Timothy E. Yen (2016)

Yong Guo (2016)

Deborah J. Culley (2017)

Yi-Hwa Choi (2017)

Juncheng Huang (2017)

Xi Xin (2017)

Lih Wang (2017)

Tak Kyu Oh (2018)

Louis de Jong (2019)

Jie Peng (2019)

Yong Guo (2019)

Emma L. Cunningham (2019)

Overall (I-squared $=98.6 \%, p=0.000)$

NOTE: Weights are from random effects analysis

a

Study

ID

Knee Arthroplasty

Rogers, M. P. (1989)

Mathieu Priner (2008)

Christopher J. Jankowski (2011)

Benjamin J. Flink (2012)

Kyu Sung Chung (2015)

Timothy E. Yen (2016)

Lih Wang (2017)

Juncheng Huang (2017)

Tak Kyu Oh (2018)

Jie Peng (2019)

Emma L. Cunningham (2019)

Subtotal (I-squared $=99.0 \%, p=0.000$ )

Hip Arthroplasty

Rogers, M. P. (1989)

Mathieu Priner (2008)

Christopher J. Jankowski (2011)

Joaquim Cerejeira (2013)

Yong Guo (2016)

Yi-Hwa Choi (2017)

Xi Xin (2017)

Jie Peng (2019)

Yong Guo (2019)

Emma L. Cunningham (2019)

Louis de Jong (2019)

Subtotal ( $($-squared $=89.8 \%, p=0.000$ )

Overall (I-squared $=98.6 \%, p=0.000$ )

NOTE: Weights are from random effects analysis

b
Incidence $(95 \% \mathrm{Cl}) \quad$ Weight

$0.28(0.15,0.41) \quad 3.45$

$0.17(0.09,0.26) \quad 4.20$

$0.14(0.08,0.19) \quad 4.55$

$0.05(0.04,0.07) \quad 4.90$

$0.15(0.08,0.22) \quad 4.37$

$0.15(0.08,0.22) \quad 4.40$

$0.10(0.07,0.13) \quad 4.84$

$0.25(0.17,0.34) \quad 4.21$

$0.37(0.27,0.46) \quad 4.03$

$0.03(0.01,0.05) \quad 4.91$

$0.22(0.14,0.31) \quad 4.21$

$0.21(0.18,0.24) \quad 4.81$

$0.07(0.03,0.10) \quad 4.81$

$0.31(0.26,0.36) \quad 4.67$

$0.01(0.00,0.01) \quad 4.95$

$0.25(0.17,0.33) \quad 4.29$

$0.18(0.14,0.23) \quad 4.69$

$0.16(0.16,0.17) \quad 4.94$

$0.26(0.22,0.30) \quad 4.75$

$0.20(0.15,0.25)-4.67$

$0.25(0.19,0.30) \quad 4.60$

$0.14(0.10,0.18) \quad 4.75$

$0.18(0.13,0.22) \quad 100.00$

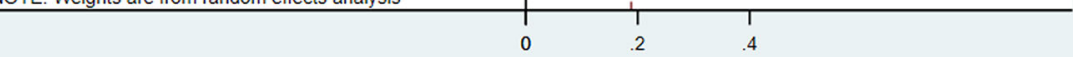

Incidence $(95 \% \mathrm{Cl})$ Weight

$0.29(0.13,0.45) \quad 3.27$

$0.23(0.11,0.36) \quad 3.78$

$0.10(0.06,0.14) \quad 4.94$

$0.25(0.17,0.34) \quad 4.43$

$0.03(0.01,0.05) \quad 5.06$

$0.22(0.14,0.31) \quad 4.44$

$0.18(0.14,0.23) \quad 4.87$

$0.01(0.00,0.01) \quad 5.10$

$0.16(0.16,0.17) \quad 5.09$

$0.22(0.15,0.30) \quad 4.54$

$0.20(0.13,0.26) \quad 4.67$

$0.16(0.10,0.23) \quad 50.19$

$0.27(0.04,0.49) \quad 2.43$

$0.09(0.01,0.16) \quad 4.58$

$0.10(0.06,0.15) \quad 4.90$

$0.37(0.27,0.46) \quad 4.27$

$0.21(0.18,0.24) \quad 4.98$

$0.31(0.26,0.36) \quad 4.85$

$0.25(0.17,0.33) \quad 4.51$

$0.18(0.12,0.25) \quad 4.71$

$0.25(0.19,0.30) \quad 4.79$

$0.09(0.04,0.13) \quad 4.87$

$0.26(0.22,0.30) \quad 4.93$

$0.21(0.16,0.26) \quad 49.81$

$0.19(0.14,0.24) \quad 100.00$

Fig. 2 Forest plots of the meta-analysis of the incidence of POD. a Incidence of POD of overall patients. $\mathbf{b}$ Incidence of POD of knee or hip replacement groups 


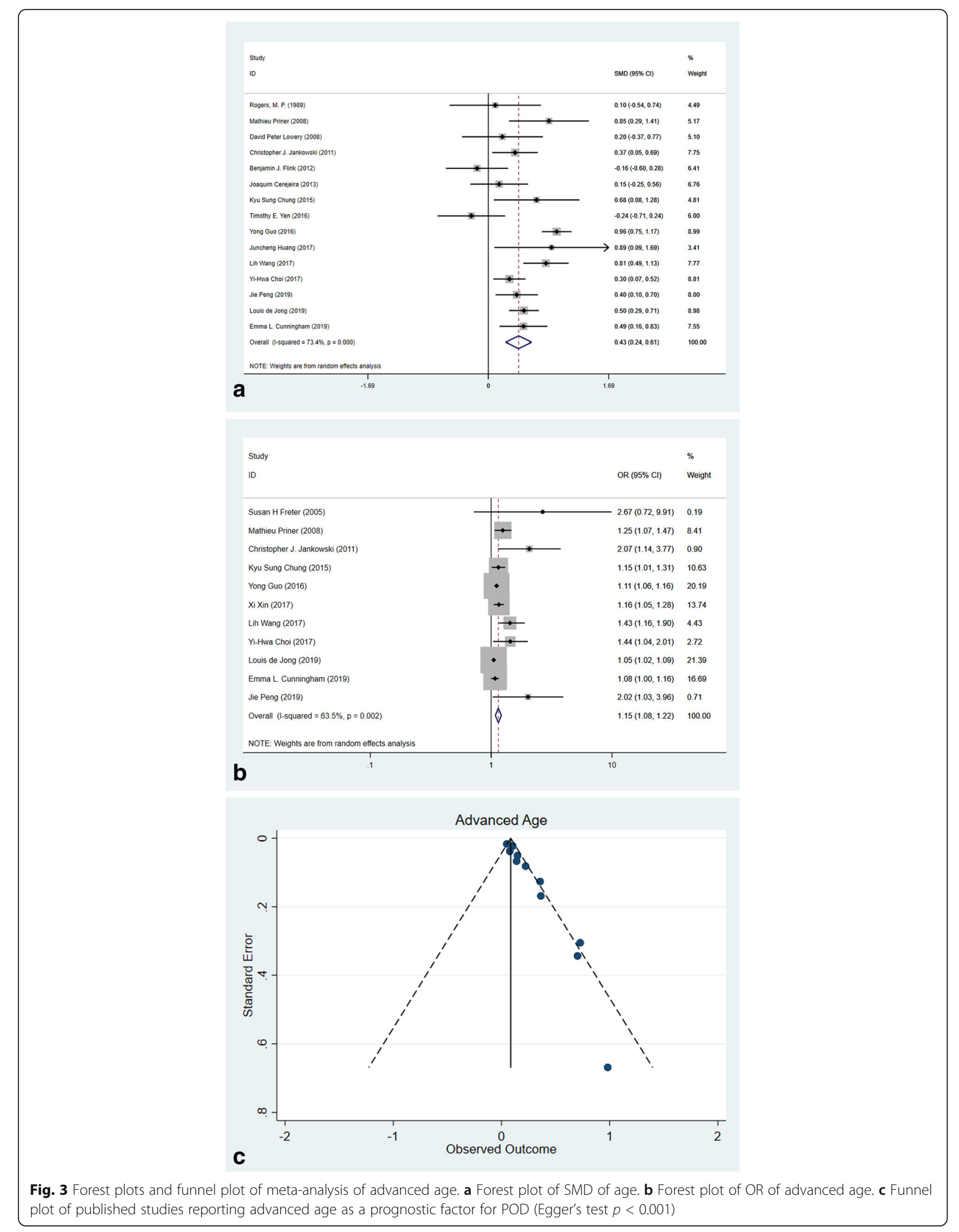




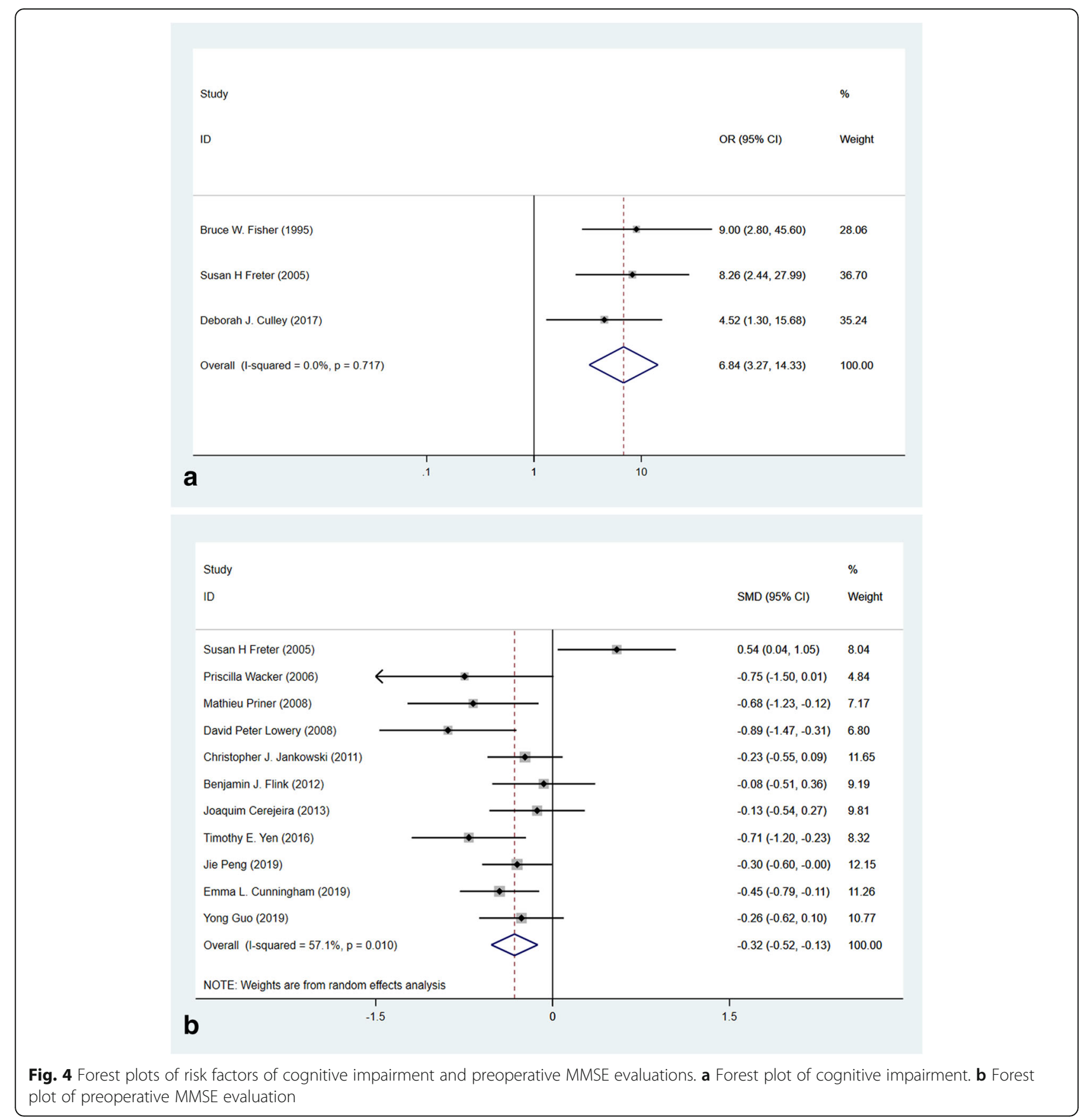

$<0.001)$. Trim-and-fill revealed that after adjusting for publication bias, the pooled OR remains at $1.12(95 \% \mathrm{CI}$ $1.05-1.19, I^{2}=64.4 \% p<0.001,5$ filled) which sustained the effect estimate was reliable.

\section{Cognitive impairment}

As a recognized risk factor for POD, most studies excluded patients with cognitive impairment for removing confounding factors. Three studies reported the patients with cognitive impairment were at higher risk of POD
(Fig. 4a, OR 6.84, 95\% CI 3.27-14.33, $p<0.001, I^{2}=$ $0.0 \%$ ) without heterogeneity. The Mini-Mental State Examination (MMSE) test is a 30-point questionnaire which is used to measure the cognitive impairment [40]; any score less than 24 indicates an abnormal cognition. In this meta-analysis, a pooled estimate from eleven studies revealed that the MMSE score in the POD group was significantly lower (Fig. 4b, SMD-0.32, 95\% CI ($\left.0.52,0.13), p=0.001, I^{2}=57.1 \%\right)$ without publication bias (Eggar's $p=0.455)$. 


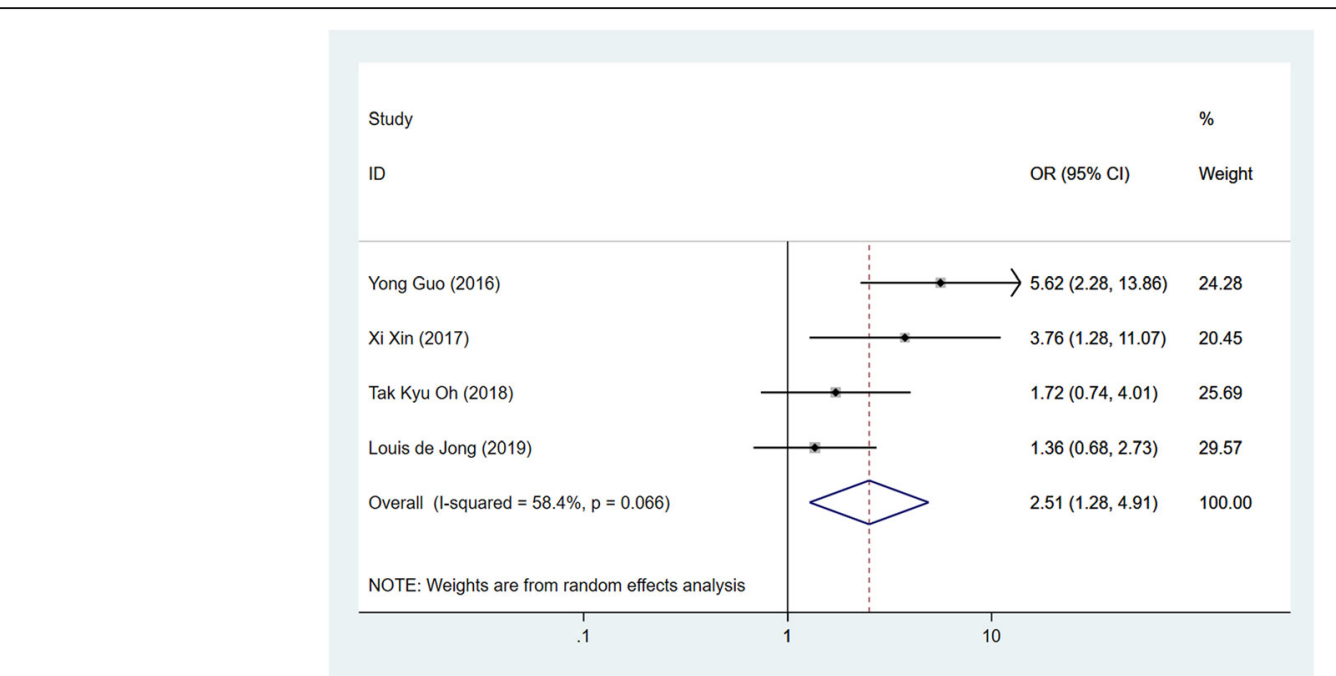

Fig. 5 Forest plot of history of cerebrovascular events as a risk factor

\section{History of cerebrovascular events}

Cerebrovascular events, stroke, and transient ischemia, etc., were defined as prognostic factors for POD [3]. Four of the included researches paid attention, and the pooled OR was 2.51 (Fig. 5, 95\% CI 1.28-4.91, $I^{2}=$ $58.4 \%, p=0.007)$ with statistical significance and mild heterogeneity.

\section{Medical comorbidities}

Common neuropsychiatric comorbidities were reported in certain studies. Dementia was identified as a prognostic factor for POD [3], and our result demonstrated dementia was a significant risk factor for POD with a pooled OR of 3.09 (Fig. 6a, 95\% CI 2.10-4.56, $p<0.001, I^{2}=38.6 \%, 5$ studies). Further, neurological disorders (Parkinson's disease, etc.) were reported in five studies and the result of meta-analysis revealed an OR of 2.26 (Fig. 6b, 95\% CI $1.23-4.15, p<0.001, I^{2}=0.0 \%$ ). Last but not the least, patients with psychiatric illness were evaluated in two studies. The pooling of data derived an OR of 2.74 (Fig. 6c, 95\% CI 1.34-5.62, $p=0.006, I^{2}=0.0 \%$ ) which confirmed the prognostic effect of psychosis.

Association has been found between sleep disturbance and POD [41]. The pooling of data from two studies which demonstrated the data between obstructive and POD derived an OR of 4.17 (Fig. 6d, 95\% CI 1.72-10.09, $\left.p=0.002, I^{2}=0.0 \%\right)$ with statistical significance.

\section{Surgical and anesthesia factors}

Performing knee or hip replacement may result in a different rate of POD. Six studies reported the POD incidence in the knee and hip replacement cohort. The meta-analysis result showed that compared with the hip replacement, knee replacement surgery derived an OR of 1.42 (Fig. 7a, 95\% CI 1.00-2.02, $p=0.048, I^{2}=9.8 \%$ ) for
POD without heterogeneity. Further, the duration of surgery of patients in the POD group was longer (Fig. 7b, SMD 0.29, 95\% CI 0.06-0.52, $p=0.013, I^{2}=57.4 \%, 7$ studies) and the blood loss was worse (Fig. 7c, SMD $0.30,95 \%$ CI $0.15-0.44, p<0.001, I^{2}=0.0 \%, 4$ studies).

On the other hand, the comparison between anesthesia types was reported by five studies. Patients who underwent spinal anesthesia were less likely to sustain POD when compared with general anesthesia and the combinable OR was 0.62 (Fig. 7d, 95\% CI 0.46-0.85, $p=0.003, I^{2}=45.7 \%$ ).

\section{Preoperative evaluation of comorbidities}

Multiple preoperative evaluations of the patients' physical status demonstrated differences existing between the POD group and the non-POD group. Eight studies reported that patients with American Society of Anesthesiologists' (ASA) score III or above were at a higher risk for developing POD (Fig. 8a, OR 1.59, 95\% CI 1.25-2.03, $\left.p<0.001, I^{2}=29.3 \%\right)$. Further, the Charlson Comorbidity Index (CCI), reported by five studies, was higher in the POD group compared with that in the non-POD group (Fig. 8b, SMD 0.35, 95\% CI 0.04-0.66, $p=0.029$, $\left.I^{2}=56.9 \%\right)$.

\section{Laboratory test}

Several preoperative laboratory indicators were presented in certain studies. Patients suffered from POD showed a lower level in total protein (Fig. 9a, 2 studies, SMD $-0.68,95 \%$ CI $(-0.87,-0.48), p<0.001, I^{2}=$ 0.0\%), albumin (Fig. 9b, 2 studies, SMD -0.77 , 95\% CI $\left.(-1.36,-0.19), p=0.009, I^{2}=71.6 \%\right)$, and preoperative hemoglobin (Fig. 9c, 6 studies, SMD $-0.58,95 \%$ CI ($\left.1.11,-0.04), p=0.034, I^{2}=94.4 \%\right)$. 


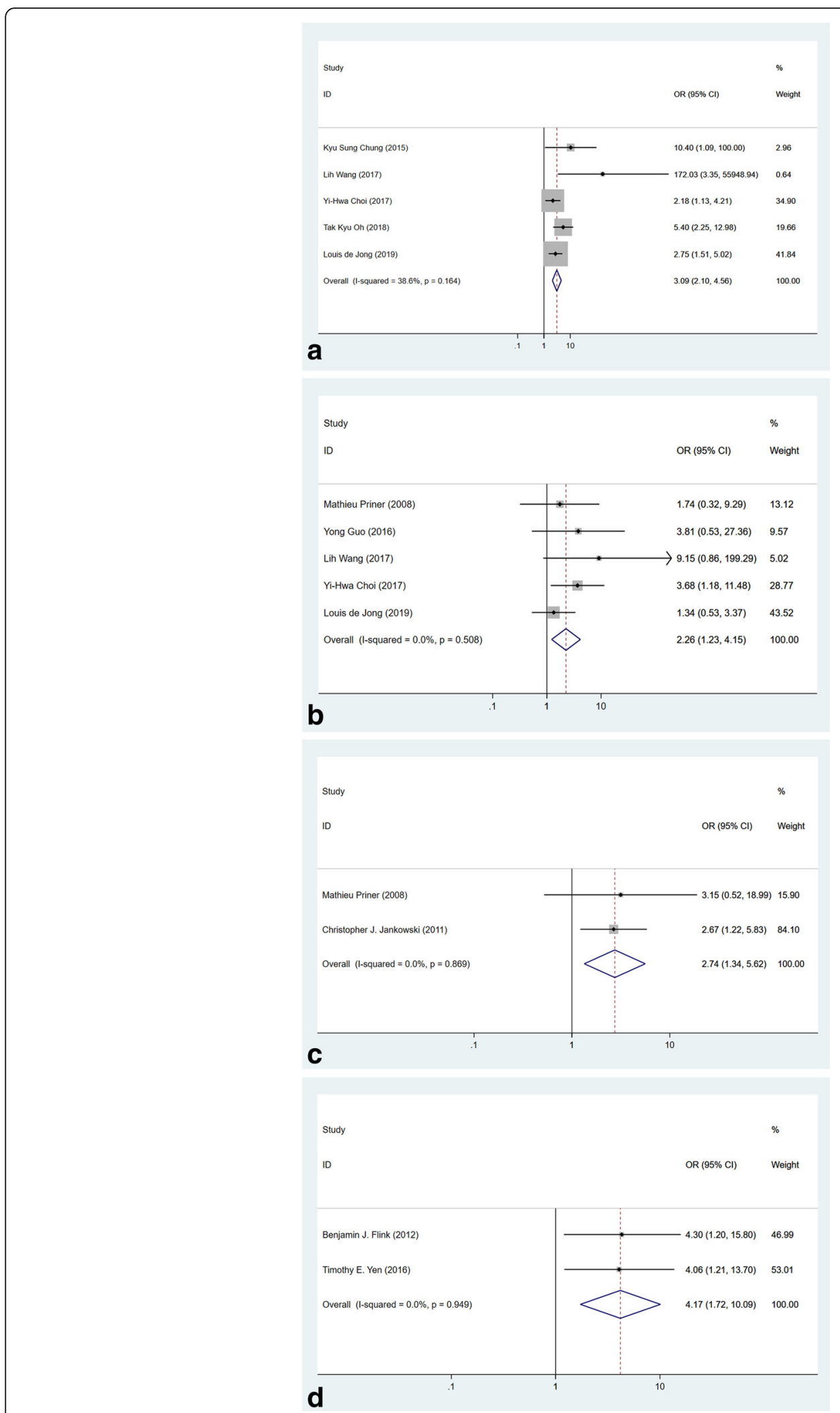

Fig. 6 Forest plots of risk factors of medical comorbidities. a Forest plot of dementia. $\mathbf{b}$ Forest plot of neurological disorders. c Forest plot of psychiatric illness. d Forest plot of obstructive sleep apnea 


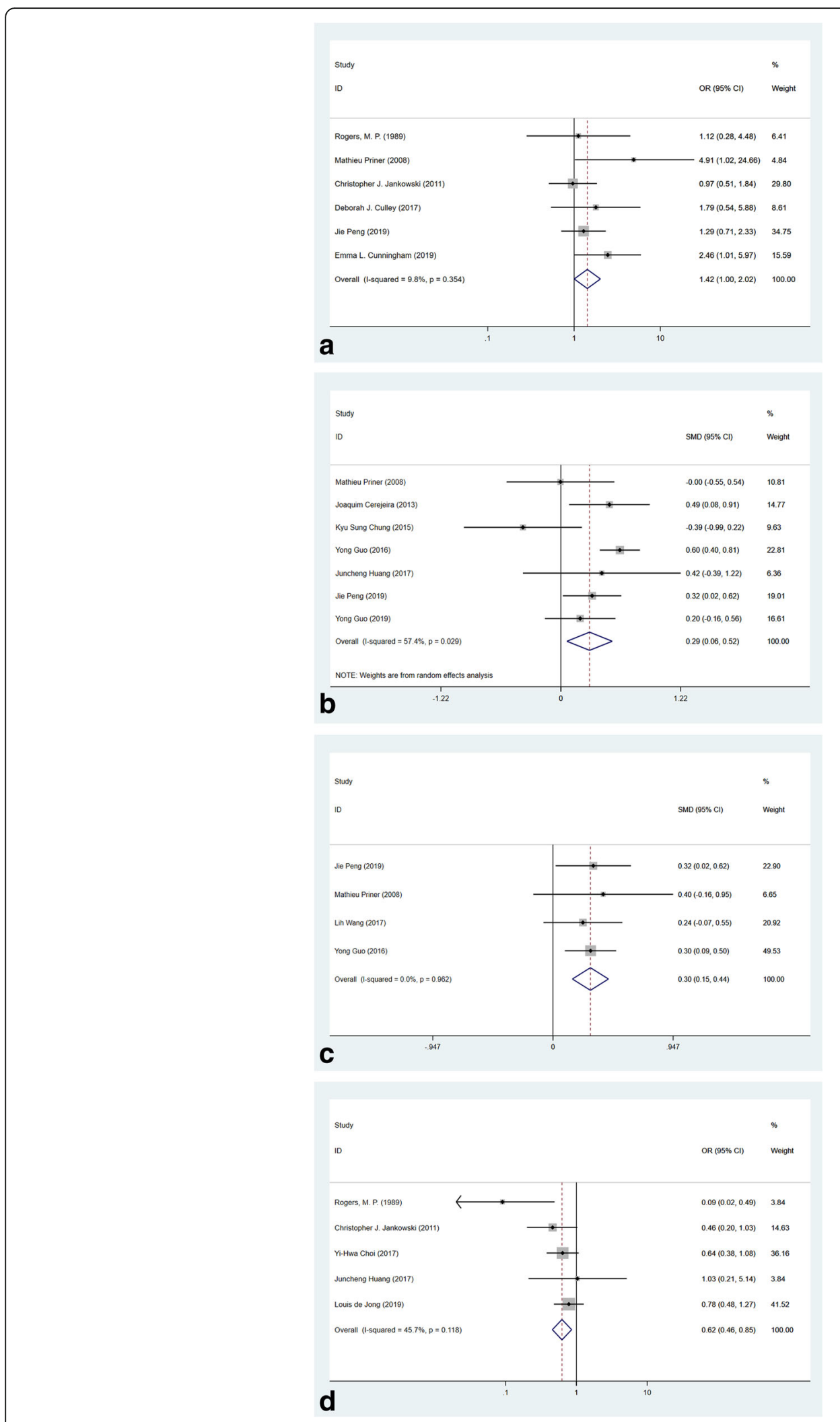

Fig. 7 Forest plots of surgical and anesthetic risk factors. a Forest plot of knee replacement (compared with hip replacement). b Forest plot of duration of surgery. c Forest plot of blood loss. $\mathbf{d}$ Forest plot of spinal anesthesia (compared with general anesthesia) 


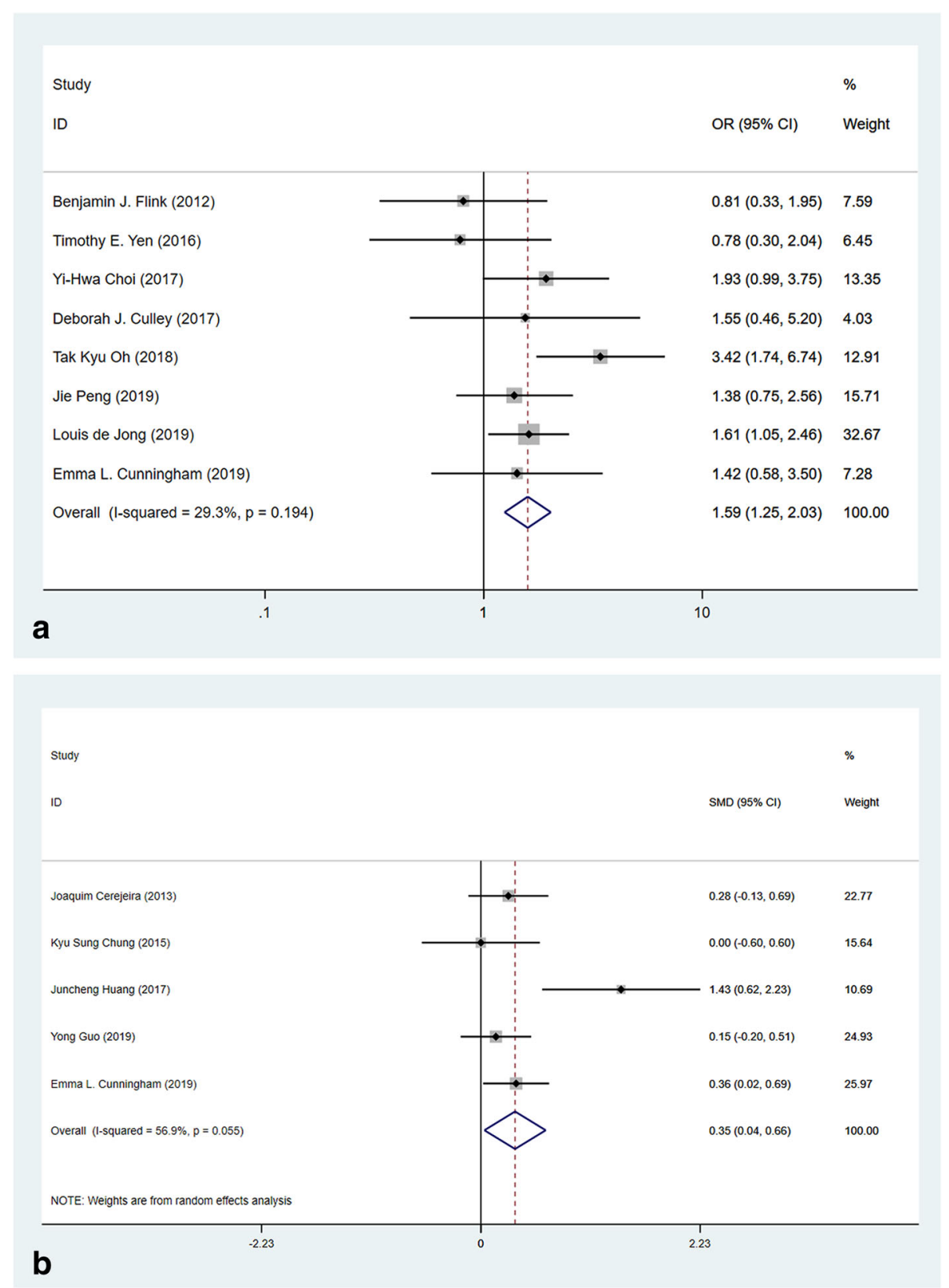

Fig. 8 Forest plots of preoperative evaluation of comorbidities in predicting POD. a Forest plot of ASA score $\geq$ III. $\mathbf{b}$ Forest plot of CCI score

\section{Discussion}

The current meta-analysis included 22 studies and presented an incidence of $17.6 \%$ (Fig. 2) in knee and hip replacement patients. It was consistent with a previous meta-analysis that concluded $17.3 \%$ of patients who underwent total joint replacement would develop POD [8]. We identified 28 potential prognostic factors, and 18 revealed statistically significant. Preoperative factors included advanced age, education, ASA and CCI scores, cognitive impairment, neuropsychiatric comorbidities, obstructive sleep apnea, and history of cerebrovascular events. Surgery-related factors were knee replacement, duration of surgery, blood loss, and general anesthesia. Significance difference existed in some laboratory markers including preoperative total protein, albumin, and hemoglobin. Besides, there was a prolonged length of stay of patients who suffered from POD (SMD - 0.53, 95\% CI (0.20, 0.87), $\left.p=0.002, I^{2}=56.7 \%\right)$.

Advanced age was a robust prognostic factor. Our study reported that the admission age was 2.7 years older in the POD group with a mild prognostic strength (OR 1.15). The previous researches demonstrated a wide 
SMD $(95 \% \mathrm{Cl}) \quad$ Weight

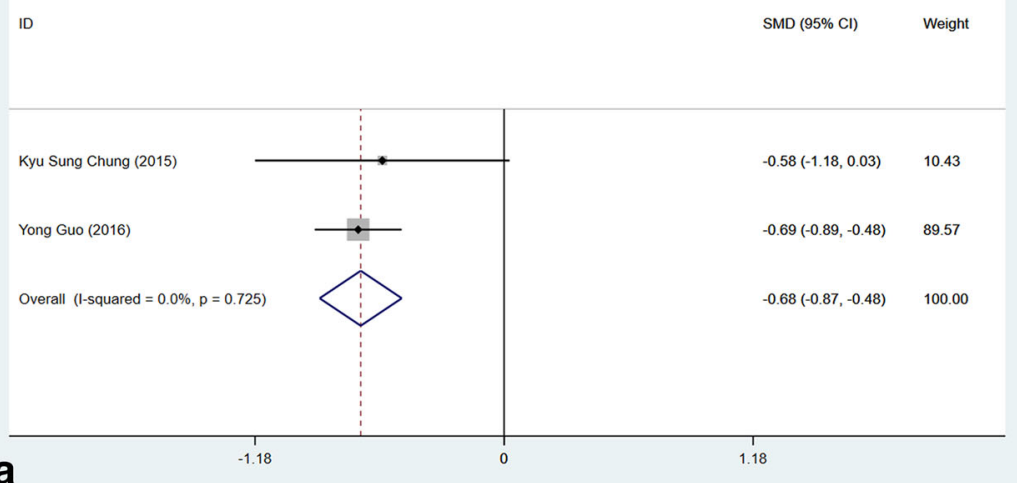

study
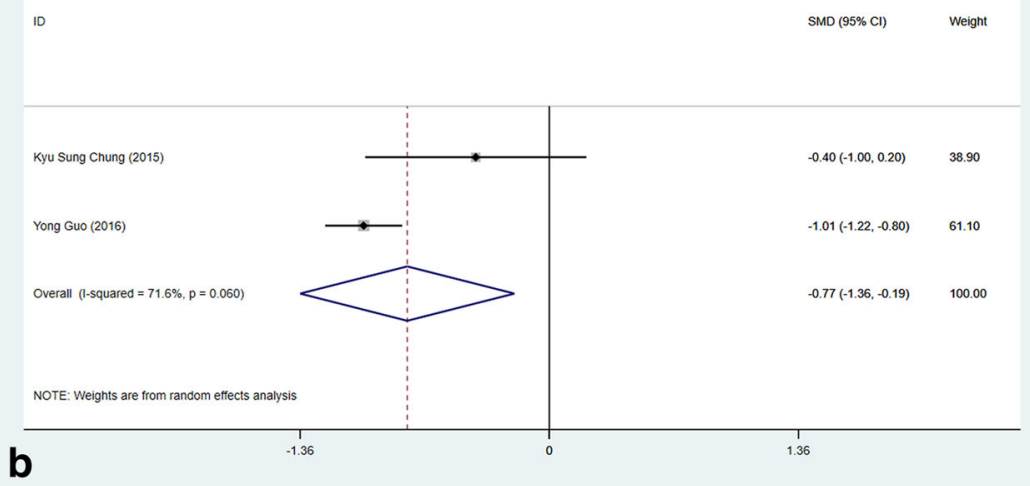

b

Study

10

SMD $(95 \% \mathrm{Cl}) \quad$ Weight

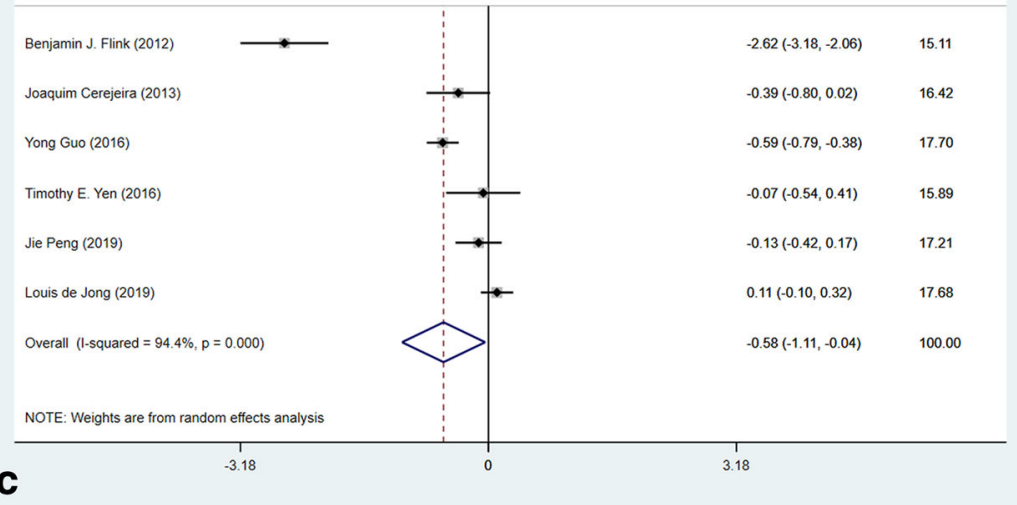

Fig. 9 Forest plots of laboratory test in predicting POD. a Forest plot of the difference of preoperative total protein. $\mathbf{b}$ Forest plot of the difference of preoperative albumin. c Forest plot of the difference of preoperative hemoglobin 
range of OR (1.07-12.95) of advanced age in surgical awards [42-44], and the possible reason was the definition of "advanced age" and surgical types differed between studies. Age-related cerebral changes in stressregulating neurotransmitter and intracellular signal transduction systems were the main reasons for the development of delirium in elderly patients [45]. Further, ASA $\geq$ III (OR 1.59) or higher CCI (SMD 0.35) were significant indicators that sustain that patients with a deteriorated physical status were susceptible to POD. A previous meta-analysis also indicated older patients with frailty had more chance of developing POD [46]. Indeed, inflammation and sickness may result in aberrant stress response under the surgical circumstance which is vulnerable to POD [47]. Generally, as the gerontic patients are the main population receiving knee or hip replacement, physical status evaluation should be routinely carried out with much attention paid to the advanced age or functional impaired ones.

Pre-existing cognitive impairment is a chronic, longterm status that may manifest as memory impairment, visuospatial disorders, word-finding difficulties, or changes in attention functions [48] while POD is described as an acute confusional state or altered mental status [49]. Consistent with previous meta-analyses [50, 51], we showed patients with pre-existing cognitive impairment are at a higher risk for developing POD (OR 6.84). The agerelated cerebral change with the effects of cerebrovascular events, which was also a prognostic factor proved in the study, can result in susceptibility to delirium when biologically stressed, especially when underlying cognitive impairment exists, not to mention surgical stress $[47,52]$. Further, patients with neuropsychiatric disorders were more susceptible to POD due to inflammation, chronic stress, neuronal damage, and impaired cholinergic function [53]. We proved that the MMSE score differs between groups significantly. It highlighted that preoperative cognitive assessment would be effective in screening potential delirium-risk patients which was verified by several studies [22, 30, 33]. Therefore, joint replacement surgeons should put the cognitive assessment in the standardized program for elective surgery [54].

Patients who developed delirium were more often those who underwent knee replacement, with longer surgical time, and suffered worse blood loss. It is unclear why knee replacement is a risk factor of POD. We suppose that firstly, the initial diagnoses of patients who underwent knee replacement were more likely inflammatory disease [1], osteoarthritis and rheumatoid arthritis, etc., and as for hip replacement trauma, dysplasia, or necrosis played a part [2]. And an inflammation state may promote the pathophysiology process of delirium [47]. Secondly, patients may suffer greater pain after knee replacement, and it indicates extension analgesic burdens which may be contributory [55]. Finally, in knee replacement, the utilization of a tourniquet was common but it would increase neuroinflammatory burden via the washout of an ischemic limb [17]. Consistently with a previous study, prolonged duration of surgery may contribute to the development of POD [56]. As theory says the possible pathophysiology of delirium is disruptions of cerebral autoregulation, which can occur during surgery [57], a prolonged surgery would result in exacerbated hypercapnia, hypothermia, and worse blood loss, which all contribute to diminished autoregulation and triggers POD. This result draws attention to the complex knee replacement operation including bilateral replacement and revision. For patients with a potential risk of POD receiving this kind of surgery, thorough preoperative planning by experienced surgeons and anesthetists was essential to guarantee the surgery would be completed safely and quickly.

Spinal anesthesia was associated with reduced OR for POD (OR 0.62). This result is consistent with several previous studies $[8,58,59]$. Recently, two high-volume retrospective population-based studies both revealed a $17-45 \%$ decrease of odds when compared with general anesthesia. However, the underlying mechanism remains controversial. The spinal anesthesia has the effect of reducing the delirium risk that may be related to the reduction of systemic anesthetic drugs which affect the central nervous system [60]. A study compared epidural with general anesthesia and found a significant mental change after total hip arthroplasty in the general anesthesia group while no change in the epidural group [61]. The explanation was that general anesthesia may lead to potential hyperventilation, reduced cardiac output, reduced cerebral blood flow, postoperative hypoxemia, and cerebral vasoconstriction which all contribute to the development of POD [61]. This result indicates general anesthesia in knee and hip replacement was a risk factor for POD. Preoperative planning of the anesthetic type to certain patients who are under a potential risk of POD would be indispensable, and, when possible, spinal anesthesia should be chosen.

There were several limitations to this study. First, we used both unadjusted ORs and adjusted ORs to pool the final estimates. Some of the studies reported only unadjusted effect measures, which limited their ability to account for possible confounders. Including these data may result in overestimated results. Second, heterogeneity existed in some outcomes. Due to the limited number of studies, the heterogeneity could not always be adequately explored. However, the random-effect model was used when $I^{2}>50 \%$, and the heterogeneity of results summarized from sufficient studies were explored and the reliability was confirmed. Third, the subtypes of the knee or hip replacement surgery were not evaluated in 
this study. Some included studies reported data from hemiarthroplasty, revision surgeries, or bilateral surgeries. Due to the lack of sufficient original data, we did not perform subgroup analysis.

Our study had several strengths. First, we presented 28 potential risk factors among which 18 were statistically significant while the previous meta-analysis only reported pooled incidence of POD in the knee and hip replacement [8], and the risk factors were summarized in a systematic review without an overall estimation of effects [9], which meant this is by far the first study to quantitatively summarize the risk factors for the postoperative delirium after knee replacement or hip replacement. Second, twenty-two studies and over 11,000 patients were included in this meta-analysis which gave us sufficient data to investigate the possible prognostic factors. Third, every included study was carefully screened with methodology assessment resulting in a moderate to high quality, which meant the extracted data was reliable.

\section{Conclusion}

In summary, this meta-analysis found POD was common in the knee or hip replacement surgery. And we identified 18 significant risk factors from patient-related and operation-related fields. Future efforts should be made to determine the risk factors in each subtype of joint replacement and which risk factors should be paid more attention to and how to quantify them. This metaanalysis suggested joint replacement surgeons perform cognitive assessment preoperatively and look into the reasons for the prognostic strength of knee replacement.

\section{Supplementary Information}

The online version contains supplementary material available at https://doi. org/10.1186/s13018-020-02127-1.

Additional file 1: Supplement file 1. PRISMA flow diagram.

Additional file 2: Supplement file 2. PRISMA checklist.

\section{Acknowledgements}

We are thankful for the support of the data analysts from the Department of Orthopedic Surgery, West China Hospital.

\section{Authors' contributions}

$X R$ provided the ideas of this study. ZC-D and XR collected the data. XR and SY-Y analyzed the data. ZC-D and HD-Y helped with the interpretation of data. The authors have read and approved the final manuscript.

\section{Funding}

This research was not funded.

\section{Availability of data and materials}

The datasets used and analyzed during the current study are available from the corresponding author on reasonable request.

\section{Ethics approval and consent to participate}

This study was approved by Institutional Review Board of West China Hospital

\section{Competing interests}

The authors declare that they have no conflict of interest.

Received: 27 April 2020 Accepted: 29 November 2020

Published online: 22 January 2021

\section{References}

1. Price AJ, Alvand A, Troelsen A, Katz JN, Hooper G, Gray A, Carr A, Beard D. Knee replacement. Lancet. 2018;392(10158):1672-82. https://doi.org/10. 1016/S0140-6736(18)32344-4.

2. Ferguson RJ, Palmer A Jr, Taylor A, Porter ML, Malchau H, Glyn-Jones S. Hip replacement. Lancet. 2018;392(10158):1662-71. https://doi.org/10.1016/ S0140-6736(18)31777-X.

3. Inouye SK, Westendorp RGJ, Saczynski JS. Delirium in elderly people. Lancet. 2014:383(9920):911-22. https://doi.org/10.1016/S0140-6736(13)60688-1.

4. Inouye SK, Marcantonio ER, Kosar CM, Tommet D, Schmitt EM, Travison TG, Saczynski JS, Ngo LH, Alsop DC, Jones RN. The short-term and long-term relationship between delirium and cognitive trajectory in older surgical patients. Alzheimers Dement. 2016;12(7):766-75. https://doi.org/10.1016/j. jalz.2016.03.005

5. Chen CC-H, Li H-C, Liang J-T, Lai IR, Purnomo JDT, Yang Y-T, Lin B-R, Huang J, Yang C-Y, Tien Y-W, Chen C-N, Lin M-T, Huang G-H, Inouye SK. Effect of a modified hospital elder life program on delirium and length of hospital stay in patients undergoing abdominal surgery: a cluster randomized clinical trial. JAMA Surg. 2017;152(9):827-34. https://doi.org/10.1001/jamasurg.2017. 1083.

6. Siddiqi N, Harrison JK, Clegg A, Teale EA, Young J, Taylor J, Simpkins SA. Interventions for preventing delirium in hospitalised non-ICU patients. Cochrane Database Syst Rev. 2016;3:CD005563. https://doi.org/10.1002/ 14651858.CD005563.pub3.

7. Sanders RD, Coburn M, Cunningham C, Pandharipande P. Risk factors for postoperative delirium. Lancet Psychiatry. 2014;1(6):404-6. https://doi.org/10. 1016/S2215-0366(14)00012-1

8. Scott JE, Mathias JL, Kneebone AC. Incidence of delirium following total joint replacement in older adults: a meta-analysis. Gen Hosp Psychiatry. 2015;37(3):223-9. https://doi.org/10.1016/j.genhosppsych.2015.02.004.

9. Bin Abd Razak HR, Yung WYA. Postoperative delirium in patients undergoing total joint arthroplasty: a systematic review. J Arthroplast. 2015; 30(8):1414-7. https://doi.org/10.1016/j.arth.2015.03.012.

10. Diagnostic and statistical manual of mental disorders: DSM-5. 5th ed. Arlington: American Psychiatric Association; 2013,.

11. Inouye SK, van Dyck CH, Alessi CA, Balkin S, Siegal AP, Horwitz Rl. Clarifying confusion: the confusion assessment method. A new method for detection of delirium. Ann Intern Med. 1990;113(12):941-8. https://doi.org/10.7326/ 0003-4819-113-12-941.

12. Trzepacz PT, Mittal D, Torres R, Kanary K, Norton J, Jimerson N. Validation of the Delirium Rating Scale-revised-98: comparison with the delirium rating scale and the cognitive test for delirium. J Neuropsychiatr Clin Neurosci. 2001;13(2):229-42. https://doi.org/10.1176/jnp.13.2.229.

13. Stang A. Critical evaluation of the Newcastle-Ottawa scale for the assessment of the quality of nonrandomized studies in meta-analyses. Eur J Epidemiol. 2010;25(9):603-5. https://doi.org/10.1007/s10654-010-9491-z.

14. Peng J, Wu G, Chen J, Chen H. Preoperative C-reactive protein/albumin ratio, a risk factor for postoperative delirium in elderly patients after total joint arthroplasty. J Arthroplast. 2019;34(11):2601-5. https://doi.org/10.1016/j. arth.2019.06.042

15. Guo Y, Li Y, Zhang Y, Fang S, Xu X, Zhao A, Zhang J, Li JV, Ma D, Jia W, Jiang W. Post-operative delirium associated with metabolic alterations following hemi-arthroplasty in older patients. Age Ageing. 2019;49(1):88-95. https://doi.org/10.1093/ageing/afz132.

16. de Jong L, van Rijckevorsel VAJIM, Raats JW, Klem TMAL, Kuijper TM, Roukema GR. Delirium after hip hemiarthroplasty for proximal femoral fractures in elderly patients: risk factors and clinical outcomes. Clin Interv Aging. 2019;14:427-35. https://doi.org/10.2147/CIA.S189760.

17. Cunningham EL, McGuinness B, McAuley DF, Toombs J, Mawhinney T, O'Brien S, Beverland D, Schott JM, Lunn MP, Zetterberg H, Passmore AP. CSF Beta-amyloid 1-42 concentration predicts delirium following elective arthroplasty surgery in an observational cohort study. Ann Surg. 2019;269(6): 1200-5. https://doi.org/10.1097/SLA.0000000000002684.

18. Oh TK, Park HY, Shin H-J, Jeon Y-T, Do S-H, Hwang J-W. The role of perioperative statin use in the prevention of delirium after total knee 
replacement under spinal anesthesia. J Arthroplast. 2018;33(12):3666-3671. e3661. https://doi.org/10.1016/j.arth.2018.08.022.

19. Xin X, Xin F, Chen X, Zhang Q, Li Y, Huo S, Chang C, Wang Q. Hypertonic saline for prevention of delirium in geriatric patients who underwent hip surgery. J Neuroinflammation. 2017;14(1):221. https://doi.org/10.1186/ s12974-017-0999-y.

20. Wang L, Seok S, Kim S, Kim K, Lee S, Lee K. The risk factors of postoperative delirium after total knee arthroplasty. J Knee Surg. 2017;30(6):600-5. https:// doi.org/10.1055/s-0036-1593872.

21. Huang J, Bin Abd Razak HR, Yeo SJ. Incidence of postoperative delirium in patients undergoing total knee arthroplasty-an Asian perspective. Ann Transl Med. 2017;5(16):321. https://doi.org/10.21037/atm.2017.06.40.

22. Culley DJ, Flaherty D, Fahey MC, Rudolph JL, Javedan H, Huang C-C, Wright J, Bader AM, Hyman BT, Blacker D, Crosby G. Poor performance on a preoperative cognitive screening test predicts postoperative complications in older orthopedic surgical patients. Anesthesiology. 2017;127(5):765-74. https://doi.org/10.1097/ALN.0000000000001859.

23. Choi Y-H, Kim D-H, Kim T-Y, Lim T-W, Kim S-W, Yoo J-H. Early postoperative delirium after hemiarthroplasty in elderly patients aged over 70 years with displaced femoral neck fracture. Clin Interv Aging. 2017;12:1835-42. https:// doi.org/10.2147/CIA.S147585.

24. Yen TE, Allen JC, Rivelli SK, Patterson SC, Metcalf MR, Flink BJ, Mirrakhimov AE, Lagoo SA, Vail TP, Young CC, Moon RE, Trzepacz PT, Kwatra MM. Association between Serum IGF-I levels and postoperative delirium in elderly subjects undergoing elective knee arthroplasty. Sci Rep. 2016;6: 20736. https://doi.org/10.1038/srep20736.

25. Guo $Y$, Jia $P$, Zhang J, Wang $X$, Jiang $H$, Jiang W. Prevalence and risk factors of postoperative delirium in elderly hip fracture patients. J Int Med Res. 2016;44(2):317-27. https://doi.org/10.1177/0300060515624936.

26. Chung KS, Lee JK, Park JS, Choi CH. Risk factors of delirium in patients undergoing total knee arthroplasty. Arch Gerontol Geriatr. 2015;60(3):443-7. https://doi.org/10.1016/j.archger.2015.01.021.

27. Cerejeira J, Batista P, Nogueira V, Vaz-Serra A, Mukaetova-Ladinska EB. The stress response to surgery and postoperative delirium: evidence of hypothalamic-pituitary-adrenal axis hyperresponsiveness and decreased suppression of the GH/IGF-1 Axis. J Geriatr Psychiatry Neurol. 2013;26(3): 185-94. https://doi.org/10.1177/0891988713495449.

28. Flink BJ, Rivelli SK, Cox EA, White WD, Falcone G, Vail TP, Young CC, Bolognesi MP, Krystal AD, Trzepacz PT, Moon RE, Kwatra MM. Obstructive sleep apnea and incidence of postoperative delirium after elective knee replacement in the nondemented elderly. Anesthesiology. 2012;116(4):78896. https://doi.org/10.1097/ALN.0b013e31824b94fc

29. Jankowski CJ, Trenerry MR, Cook DJ, Buenvenida SL, Stevens SR, Schroeder $\mathrm{DR}$, Warner DO. Cognitive and functional predictors and sequelae of postoperative delirium in elderly patients undergoing elective joint arthroplasty. Anesth Analg. 2011;112(5):1186-93. https://doi.org/10.1213/ ANE.0b013e318211501b.

30. Priner M, Jourdain M, Bouche G, Merlet-Chicoine I, Chaumier J-A, Paccalin M. Usefulness of the short IQCODE for predicting postoperative delirium in elderly patients undergoing hip and knee replacement surgery. Gerontology. 2008;54(2):116-9. https://doi.org/10.1159/000117574.

31. Lowery DP, Wesnes K, Brewster N, Ballard C. Quantifying the association between computerised measures of attention and confusion assessment method defined delirium: a prospective study of older orthopaedic surgical patients, free of dementia. Int J Geriatr Psychiatry. 2008;23(12):1253-60. https://doi.org/10.1002/gps.2059.

32. Wacker $P$, Nunes PV, Cabrita H, Forlenza OV. Post-operative delirium is associated with poor cognitive outcome and dementia. Dement Geriatr Cogn Disord. 2006;21(4):221-7. https://doi.org/10.1159/000091022.

33. Freter $\mathrm{SH}$, Dunbar MJ, MacLeod H, Morrison M, MacKnight C, Rockwood K. Predicting post-operative delirium in elective orthopaedic patients: the Delirium Elderly At-Risk (DEAR) instrument. Age Ageing. 2005;34(2):169-71. https://doi.org/10.1093/ageing/afh245.

34. Fisher BW, Flowerdew G. A simple model for predicting postoperative delirium in older patients undergoing elective orthopedic surgery. J Am Geriatr Soc. 1995:43(2):175-8. https://doi.org/10.1111/j.1532-5415.1995. tb06385.x.

35. Rogers MP, Liang MH, Daltroy LH, Eaton H, Peteet J, Wright E, Albert M. Delirium after elective orthopedic surgery: risk factors and natural history. Int J Psychiatry Med. 1989;19(2):109-21. https://doi.org/10.2190/2q3v-hyt4nn49-bpr4.
36. Cerejeira J, Batista P, Nogueira V, Firmino H, Vaz-Serra A, MukaetovaLadinska EB. Low preoperative plasma cholinesterase activity as a risk marker of postoperative delirium in elderly patients. Age Ageing. 2011;40(5): 621-6. https://doi.org/10.1093/ageing/afr053.

37. Cerejeira J, Nogueira V, Luís P, Vaz-Serra A, Mukaetova-Ladinska EB. The cholinergic system and inflammation: common pathways in delirium pathophysiology. J Am Geriatr Soc. 2012;60(4):669-75. https://doi.org/10. 1111/j.1532-5415.2011.03883.x.

38. Cunningham EL, Mawhinney T, Beverland D, O'Brien S, McAuley DF, Cairns R, Passmore P, McGuinness B. Observational cohort study examining apolipoprotein E status and preoperative neuropsychological performance as predictors of postoperative delirium in an older elective arthroplasty population. Age Ageing. 2017; 46(5):779-86. https://doi.org/10.1093/ageing/afx042.

39. Guo $Y$, Zhang $Y$, Jia P, Wang W, Zhou Q, Sun L, Zhao A, Zhang X, Wang X, Li Y, Zhang J, Jiang W. Preoperative serum metabolites are associated with postoperative delirium in elderly hip-fracture patients. J Gerontol A Biol Sci Med Sci. 2017;72(12):1689-96. https://doi.org/10.1093/gerona/glx001.

40. Pangman VC, Sloan J, Guse L. An examination of psychometric properties of the mini-mental state examination and the standardized mini-mental state examination: implications for clinical practice. Appl Nurs Res. 2000;13(4):209_ 13. https://doi.org/10.1053/apnr.2000.9231.

41. Fadayomi AB, Ibala R, Bilotta F, Westover MB, Akeju O. A systematic review and meta-analysis examining the impact of sleep disturbance on postoperative delirium. Crit Care Med. 2018;46(12):e1204-12. https://doi.org/ 10.1097/CCM.0000000000003400.

42. Zhu C, Wang B, Yin J, Xue Q, Gao S, Xing L, Wang H, Liu W, Liu X. Risk factors for postoperative delirium after spinal surgery: a systematic review and meta-analysis. Aging Clin Exp Res. 2019. https://doi.org/10.1007/s4052040019-01319-y, https://doi.org/10.1007/s40520-019-01319-y.

43. Kubota K, Suzuki A, Onde S, Yamada U, Hosaka T, Okuno F, Fujitani I, Koitabashi A, Shimada G, Kishida A. Age is the most significantly associated risk factor with the development of delirium in patients hospitalized for more than five days in surgical wards: retrospective cohort study. Ann Surg. 2018;267(5):874-7. https://doi.org/10.1097/SLA.0000000000002347.

44. Watt J, Tricco AC, Talbot-Hamon C, Pham B, Rios P, Grudniewicz A, Wong C, Sinclair D, Straus SE. Identifying older adults at risk of delirium following elective surgery: a systematic review and meta-analysis. J Gen Intern Med. 2018;33(4):500-9. https://doi.org/10.1007/s11606-017-4204-x.

45. van der Mast RC. Pathophysiology of delirium. J Geriatr Psychiatry Neurol. 1998;11(3):138-45; discussion 157-138. https://doi.org/10.1177/ 089198879801100304

46. Persico I, Cesari M, Morandi A, Haas J, Mazzola P, Zambon A, Annoni G, Bellelli G. Frailty and delirium in older adults: a systematic review and metaanalysis of the literature. J Am Geriatr Soc. 2018;66(10):2022-30. https://doi. org/10.1111/jgs.15503.

47. Maclullich AM, Ferguson KJ, Miller T, de Rooij SE, Cunningham C. Unravelling the pathophysiology of delirium: a focus on the role of aberrant stress responses. J Psychosom Res. 2008;65(3):229-38. https://doi.org/10. 1016/j.jpsychores.2008.05.019.

48. Langa KM, Levine DA. The diagnosis and management of mild cognitive impairment: a clinical review. Jama. 2014;312(23):2551-61. https://doi.org/10. 1001/jama.2014.13806.

49. Marcantonio ER. Delirium in hospitalized older adults. N Engl J Med. 2017; 377(15):1456-66. https://doi.org/10.1056/NEJMcp1605501.

50. Luan Erfe BM, Boehme J, Erfe JM, Brovman EY, Bader AM, Urman RD. Postoperative outcomes in primary total knee arthroplasty patients with preexisting cognitive impairment: a systematic review. Geriatr Orthop Surg Rehabil. 2018;9:2151459318816482. https://doi.org/10.1177/ 2151459318816482.

51. Viramontes O, Luan Erfe BM, Erfe JM, Brovman EY, Boehme J, Bader AM, Urman RD. Cognitive impairment and postoperative outcomes in patients undergoing primary total hip arthroplasty: a systematic review. J Clin Anesth. 2019;56:65-76. https://doi.org/10.1016/j.jclinane.2019.01.024.

52. Cole MG. Delirium in elderly patients. Am J Geriatr Psychiatry. 2004; 12(1):7-21.

53. Fong TG, Davis $D$, Growdon ME, Albuquerque A, Inouye SK. The interface between delirium and dementia in elderly adults. Lancet Neurol. 2015;14(8): 823-32. https://doi.org/10.1016/S1474-4422(15)00101-5.

54. Hanson MR, Gálvez-Jiménez N. Management of dementia and acute confusional states in the perioperative period. Neurol Clin. 2004;22(2):vii422. https://doi.org/10.1016/j.ncl.2004.01.001. 
55. Vaurio LE, Sands LP, Wang Y, Mullen EA, Leung JM. Postoperative delirium: the importance of pain and pain management. Anesth Analg. 2006;102(4): 1267-73. https://doi.org/10.1213/01.ane.0000199156.59226.af.

56. Ravi B, Pincus D, Choi S, Jenkinson R, Wasserstein DN, Redelmeier DA. Association of duration of surgery with postoperative delirium among patients receiving hip fracture repair. JAMA Netw Open. 2019;2(2):e190111. https://doi.org/10.1001/jamanetworkopen.2019.0111.

57. Goettel N, Burkhart CS, Rossi A, Cabella BCT, Berres M, Monsch AU, Czosnyka M, Steiner LA. Associations between impaired cerebral blood flow autoregulation, cerebral oxygenation, and biomarkers of brain injury and postoperative cognitive dysfunction in elderly patients after major noncardiac surgery. Anesth Analg. 2017;124(3):934-42. https://doi.org/10. 1213/ANE.0000000000001803.

58. Weinstein SM, Poultsides L, Baaklini LR, Mörwald EE, Cozowicz C, Saleh JN, Arrington MB, Poeran J, Zubizarreta N, Memtsoudis SG. Postoperative delirium in total knee and hip arthroplasty patients: a study of perioperative modifiable risk factors. Br J Anaesth. 2018;120(5):999-1008. https://doi.org/ 10.1016/j.bja.2017.12.046.

59. Memtsoudis S, Cozowicz C, Zubizarreta N, Weinstein SM, Liu J, Kim DH, Poultsides L, Berger MM, Mazumdar M, Poeran J. Risk factors for postoperative delirium in patients undergoing lower extremity joint arthroplasty: a retrospective population-based cohort study. Reg Anesth Pain Med. 2019:rapm-2019-100700. https://doi.org/10.1136/rapm-2019100700

60. Praticò C, Quattrone D, Lucanto T, Amato A, Penna O, Roscitano C, Fodale $\checkmark$. Drugs of anesthesia acting on central cholinergic system may cause postoperative cognitive dysfunction and delirium. Med Hypotheses. 2005;65(5): 972-82. https://doi.org/10.1016/j.mehy.2005.05.037.

61. Hole A, Terjesen T, Breivik H. Epidural versus general anaesthesia for total hip arthroplasty in elderly patients. Acta Anaesthesiol Scand. 1980;24(4):27987. https://doi.org/10.1111/j.1399-6576.1980.tb01549.x.

\section{Publisher's Note}

Springer Nature remains neutral with regard to jurisdictional claims in published maps and institutional affiliations.

Ready to submit your research? Choose BMC and benefit from:

- fast, convenient online submission

- thorough peer review by experienced researchers in your field

- rapid publication on acceptance

- support for research data, including large and complex data types

- gold Open Access which fosters wider collaboration and increased citations

- maximum visibility for your research: over $100 \mathrm{M}$ website views per year

At $\mathrm{BMC}$, research is always in progress.

Learn more biomedcentral.com/submissions 